\title{
The structure of the unstructured: mosaic of tau protein linear motifs obtained by high-resolution techniques and molecular simulation
}

\author{
Ondrej Cehlar ${ }^{1} \oplus$, Olga Bagarova ${ }^{1,2,3}$, Lenka Hornakova $^{1,2,4}$ and Rostislav Skrabana ${ }^{1}$ \\ ${ }^{1}$ Institute of Neuroimmunology, Slovak Academy of Sciences, Bratislava, Slovakia \\ ${ }^{2}$ Department of Biochemistry, Faculty of Natural Sciences, Comenius University, Bratislava, Slovakia \\ ${ }^{3}$ Institute of Experimental Physics, Department of Biophysics, Slovak Academy of Sciences, Kosice, Slovakia \\ ${ }^{4}$ Institute of Medical Chemistry, Biochemistry and Clinical Biochemistry, Medical Faculty, Comenius University, Bratislava, \\ Slovakia
}

\begin{abstract}
Intrinsically disordered proteins are flexible molecules with important physiological functions. Their mode of action often involves short segments, called linear motifs, which may exhibit distinct structural propensities. Tau is intrinsically disordered, microtubule-associated protein involved in the pathogenesis of various tauopathies. In this review we analyze the collection of 3D structures of tau local linear motifs gained from the deposited structures of tau complexes with various binding partners as well as of tau-tau complexes; determined by X-ray and electron crystallography, single-particle electron microscopy, NMR spectroscopy and molecular dynamics simulations. Insights into the partially stabilized conformations of tau linear motifs are valuable for understanding the physiological and pathological processes involving tau protein.
\end{abstract}

Key words: Tau protein - Conformation - Linear motif - Antibody - X-ray crystallography

Abbreviations: FRET, fluorescence resonance energy transfer; MTBD, microtubule binding domain; MTBR, microtubule binding repeat; PHF, paired helical filament; PRE, paramagnetic relaxation enhancement.

\section{Introduction}

Intrinsically disordered proteins and protein regions (IDPs/ IDRs) form a distinct, recently identified structural and functional entity of the proteome of all kingdoms of life (Dyson and Wright 2005). IDPs don't attain a constant 3D structure under physiological conditions, having a relatively flat energy landscape with many shallow minima that can be described as a conformational ensemble of fluctuating structures (Fisher and Stultz 2011). IDPs are highly abundant in nature and their functional repertoire supplements the

Correspondence to: Ondrej Cehlar, Institute of Neuroimmunology, Slovak Academy of Sciences, Dubravska cesta 9, 84510 Bratislava, Slovakia

E-mail: ondrej.cehlar@savba.sk functions of globular proteins. However, many IDPs play a role in the pathogenesis of human diseases e.g. neurodegenerative diseases, cancer and diabetes (Uversky et al. 2008).

In contrast to folded globular proteins, which often interact by means of a large contact area supported by protein tertiary structure, IDPs use for their interactions independently behaving short segments called linear motifs. Despite their short length and lack of stable structure, linear motifs may have detectable structural propensities, which often resemble bound-state conformations. Molecular dynamics (MD) simulations are able to detect conformational ensembles of linear motifs in uncomplexed state, giving a clue to their interaction potential (Cino et al. 2013a). For example, among 10 disordered binding partners of the Kelch domain of the hub protein Keap1, the highest affinity was measured for those that resembled the bound-state like conformation

(C) The Authors 2021. This is an open access article under the terms of the Creative Commons Attribution-NonCommercial 4.0 International License (https://creativecommons.org/licenses/by-nc/4.0/), which permits non-commercial use, distribution, and reproduction in any medium, provided the original work is properly cited. 
to the highest extent during MD simulation (Cino et al. 2013b). Therefore, intramolecular contacts in an intrinsically disordered region may serve as important intermolecular binding determinants (Davey 2019).

Neuronal protein tau is a representative member of the group of IDPs. The conversion of tau from physiological disordered form to rigid amyloid fibres is the hallmark of severe diseases - neurodegenerative tauopathies including Alzheimer's disease (AD). The driving forces and atomic details of this metamorphosis are largely unknown and insights into the conformational preferences of tau partial segments may bring important clues.

The main physiological role of tau protein is to stabilize microtubules and regulate their dynamics but tau is also involved in actin binding, neuroplasticity, axonal transport and axonal sprouting, cell cycle regulation, synaptic transmission and interactions with plasma membrane (Castellani and Perry 2019).

The alternative splicing of MAPT gene produces six tau protein isoforms present in CNS, which differ in the presence or absence of $\mathrm{N}$-terminal inserts (none, one or two) and by the presence of three (3R isoforms) or four (4R isoforms) microtubule binding repeat regions (MTBR) (Goedert et al. 1989). Longer tau isoforms with large $\mathrm{N}$ terminal insertions are expressed in peripheral nervous system (Fischer and Baas 2020). Whereas the length of CNS tau isoforms ranges from 352 to 441 amino acids, the longest peripheral tau isoform is 758 amino acids long (UniProt entry P10636). Based on sequence characteristics and function, tau molecule can be divided into the

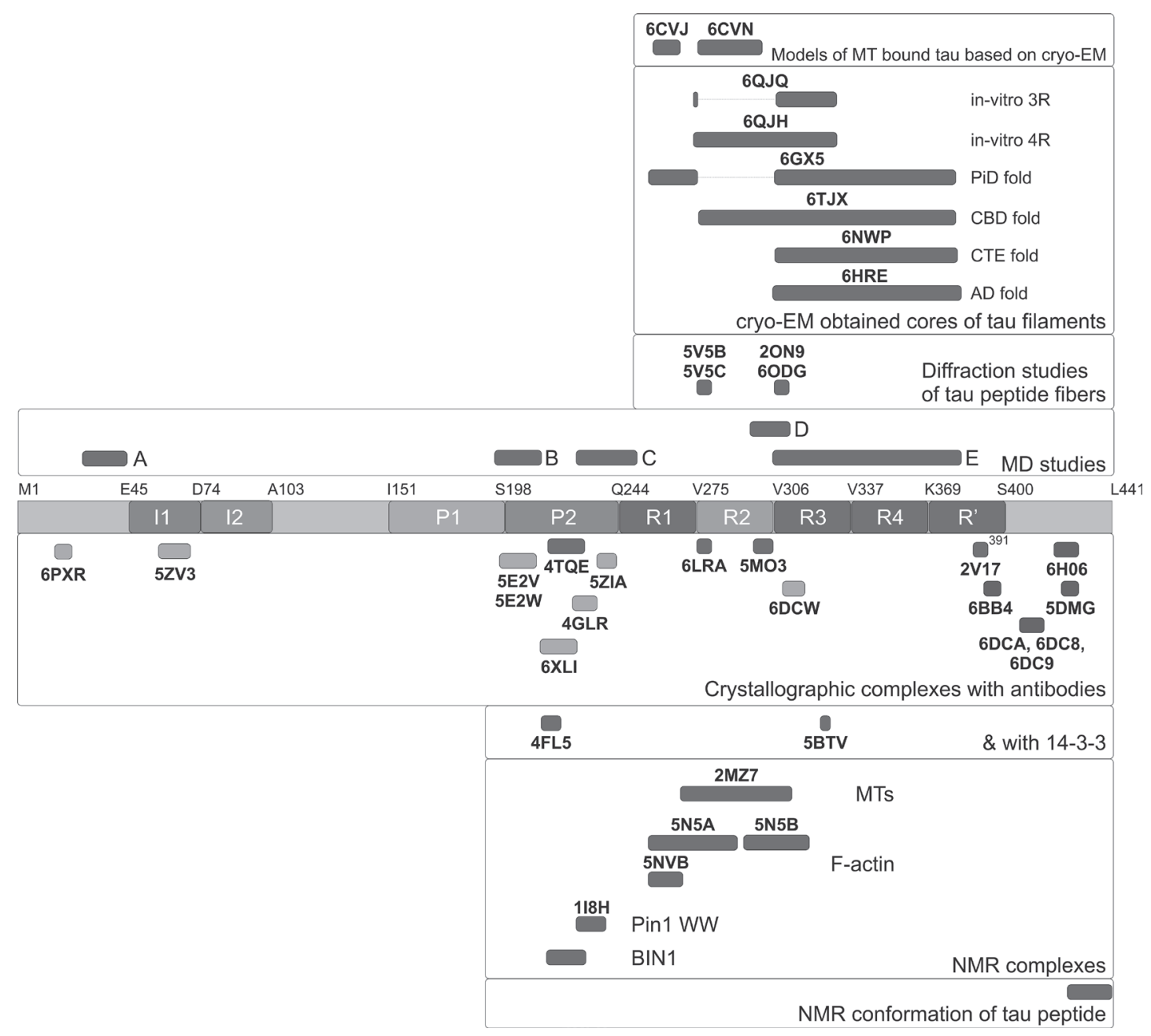

Figure 1. Positional scheme of local tau structures obtained by different methods mentioned in this review relative to the domain structure of the longest human tau isoform 2N4R (tau40) with N-terminal inserts I1, I2, proline-rich regions P1, P2, MTBRs R1-R4 and region following repeats R. Position of tau peptide is shown with corresponding PDB ID, if available. Depicted tau peptides that were subjects of MD studies: A, N-terminal tau fragment 26-44 (Perini et al. 2019); B, AT8 epitope phospho-peptide (Gandhi et al. 2015); C, Tau phospho-peptide 225-250 (Lyons et al. 2014); D, R2-R3 interface (Chen et al. 2019); E, AD PHF core dimer (Derreumaux et al. 2020). 
$\mathrm{N}$-terminal projection domain (amino acids 1-150, numbering of the longest CNS isoform), proline-rich region (151-243), microtubule binding domain (MTBD, 244-399) and C-terminal tail (400-441). Tau protein can undergo many posttranslational modifications: phosphorylation, truncation, glycosylation, glycation, nitration, ubiquitination, SUMOylation, prolyl isomerization, acetylation that have structural and functional implications.

Disruption of finely tuned network of specific albeit weak interactions mediated by (pre)structured linear motifs in the tau molecule may be the turning point of neurodegeneration. Small molecules predicted to bind computationally identified structural motifs in the tau aggregation domain were able to delay tau aggregation in vitro (Baggett and Nath 2018). Transiently populated linear motifs identified by MD or high-resolution experimental techniques may therefore represent potential druggable targets for tauopathy treatment.

The preferred conformations of linear motifs in the otherwise disordered tau molecule may constitute immunodominant hotspots, recognised by binders of naïve B-cell

Table 1. Tau structures of nonredundant segments obtained by X-ray or electron crystallography

\begin{tabular}{|c|c|c|c|c|}
\hline PDB ID & Antibody name & Tau peptide modelled & $\begin{array}{l}\text { Tau peptide used for } \\
\text { crystallization }\end{array}$ & $\begin{array}{l}\text { Resolution } \\
\text { (A) }\end{array}$ \\
\hline \multicolumn{5}{|c|}{ X-ray crystallography } \\
\hline \multicolumn{5}{|c|}{ Binding partner: Antibody Fab fragment } \\
\hline 6PXR & IPN002 (Sopko et al. 2020) & ${ }^{15}$ AGTYGLGD $^{22}$ (Fig. 2A) & $9-26$ & 1.56 \\
\hline $5 \mathrm{ZV} 3$ & CBTAU28.1 (Apetri et al. 2018) & ${ }^{57}$ EEPGSETSDAKS ${ }^{68}$ (Fig. 2B) & $52-71$ & 2.09 \\
\hline $5 \mathrm{E} 2 \mathrm{~V}$ & AT8 (Malia et al. 2016) & ${ }^{201}$ GpSPGpTPGSR ${ }^{209}$ & $194-211(\mathrm{pS} 202, \mathrm{~T} 205)$ & 1.64 \\
\hline $5 \mathrm{E} 2 \mathrm{~W}$ & AT8 (Malia et al. 2016) & ${ }^{202}$ pSPGpTPGpSR ${ }^{209}$ (Fig. 2C,U) & 194-211 (pS202, pT205, pS208) & 1.50 \\
\hline 6XLI & PT3 (Van Kolen et al. 2020) & ${ }^{210}$ SRpTPSLPpTPPTRE ${ }^{222}$ (Fig. 2D) & $210-222$ & 2.00 \\
\hline 4TQE & TAU5 (Cehlar et al. 2015) & ${ }^{215}$ LPTPPTREPKKVAVVR ${ }^{230}$ (Fig. 2E) & $201-230$ & 1.65 \\
\hline $4 \mathrm{GLR}$ & $\begin{array}{l}\text { Ultra-specific Avian Antibody (Shih et al. } \\
\text { 2012) }\end{array}$ & ${ }^{225}{ }^{K V A V V R p T P P K}{ }^{234}$ (Fig. 2F) & $224-240$ & 1.90 \\
\hline 5ZIA & CBTAU-24.1 (Zhang et al. 2018) & ${ }^{235}$ SPSpSAKSRL ${ }^{243}$ (Fig. 2G) & $221-245(\mathrm{pT} 231, \mathrm{pS} 238)$ & 2.60 \\
\hline 6LRA & Tau2r3 (Tsuchida et al. 2020) & ${ }^{275}$ VQIINK $^{280}$ (Fig. 2H) & $275-280$ & 1.90 \\
\hline $5 \mathrm{MO} 3$ & DC8E8 (Skrabana et al. 2017) & ${ }^{298}{ }^{K H V P G G G S}{ }^{305}$ (Fig. 2I,W) & $298-311$ & 1.69 \\
\hline 6DCW & CBTAU-27.1 (Apetri et al. 2018) & 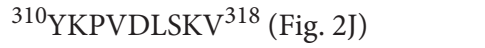 & $299-318$ & 2.00 \\
\hline $2 \mathrm{~V} 17$ & MN423 (Sevcik et al. 2007) & ${ }^{386}{ }^{\text {TDHGAE }}{ }^{391}$ (Fig. 2K) & dGAE (297-391) & 1.65 \\
\hline $6 \mathrm{BB} 4$ & C5.2 (Chukwu et al. 2018) & ${ }^{392}$ IVYKpSPV $^{398}$ (Fig. 2L) & 386-408 (pS396, pS404) & 2.10 \\
\hline $6 \mathrm{DCA}$ & 6b2 (Chukwu et al. 2019) & ${ }^{403}$ TSPRHL $^{408}$ (Fig. 2M) & $379-408$ & 2.59 \\
\hline 6DC8 & 8b2 (Chukwu et al. 2019) & ${ }^{404}{ }^{\text {SPRHL }}{ }^{408}$ (Fig. $2 \mathrm{~N}$ ) & $379-408$ & 1.79 \\
\hline 6DC9 & h4E6 (Chukwu et al. 2019) & ${ }^{403}$ TpSPRHL $^{408}$ (Fig. 2O) & 386-408 (pS404) & 2.99 \\
\hline $5 \mathrm{DMG}$ & RB86 (Bujotzek et al. 2016) & ${ }^{419}{ }^{M V D p S P Q L A T L A D}{ }^{430}$ (Fig. 2P) & $416-430$ & 2.50 \\
\hline $6 \mathrm{H} 06$ & CBTAU22.1 (van Ameijde et al. 2018) & ${ }^{418}{ }^{\text {DMVDpSPQLAT }}{ }^{427}$ (Fig. 2T) & $404-429$ & 2.63 \\
\hline \multicolumn{5}{|c|}{ Binding partner: $14-3-3$} \\
\hline 4FL5 & $14-3-3 \sigma$ (Joo et al. 2015) & ${ }^{211}$ RTPpSLPTP ${ }^{218}$ (Fig. 2Q) & $210-218(\mathrm{pS} 214)$ & 1.90 \\
\hline $5 \mathrm{BTV}$ & $14-3-3 \sigma($ Joo et al. 2015) & ${ }^{323}$ GpSLG $^{326}$ (Fig. 2R) & $320-328(\mathrm{pS} 324)$ & 1.70 \\
\hline \multicolumn{5}{|c|}{ Binding partner: Tau peptide - fibril } \\
\hline & Tau peptide sequence & Type of interface observed ${ }^{*}$ & & \\
\hline 2ON9 & VQIVYK (Sawaya et al. 2007) & Class 1 , face-to-face & & 1.51 \\
\hline 6ODG & SVQIVY (Seidler et al. 2019) & $\begin{array}{l}\text { Class } 1 \text {, face-to-face } \\
\text { Class } 3 \text {, face-to-face }\end{array}$ & & 1.00 \\
\hline \multicolumn{5}{|c|}{ Electron crystallography } \\
\hline $5 \mathrm{~V} 5 \mathrm{~B}$ & KVQIINKKLD (Seidler et al. 2018) & $\begin{array}{l}\text { Class 1, face-to-face } \\
\text { Interface A: formed by VQIIN } \\
\text { Interface B: formed by KKLD }\end{array}$ & & 1.50 \\
\hline $5 \mathrm{~V} 5 \mathrm{C}$ & VQIINK (Seidler et al. 2018) & Class 4, face-to-back (Fig. 3F) & & 1.25 \\
\hline
\end{tabular}

* Classification of steric zippers can be found in Sawaya et al. (2007) or Eisenberg and Sawaya (2017). 
repertoire. Indeed, immunization of mice with the $0 \mathrm{~N} 4 \mathrm{R}$ tau protein isoform has revealed five large regions predominantly populated by tau immunogenic sequences - two in $\mathrm{N}$-terminal projection domain $(9-15,21-27)$, two in proline -rich region (168-174 and 220-228) and one in C-terminal tail (427-438) (Selenica et al. 2014).

Similarly, memory B cells from healthy donors selected against phosphorylated tau peptides identified naturally occurring, somatically mutated tau binding antibodies in these regions (Pascual et al. 2017).

The structure of tau in the complexes with naturally evolved binders may conserve preferred conformations of tau linear interaction motifs. Following this line of thinking, we have gathered all tau conformations in the PDB originated from soluble tau complexes (Fig. 1). 3D structures of tau are obtained mainly by X-ray crystallography, but several structures come also from electron crystallography, NMR and single-particle cryo-EM. Some experimental data are being corroborated with MD simulations. The principal tau binding partners are antibody Fab fragments; other tau binders are 14-3-3s protein, Pin1 WW domain, F-actin, BIN-1, and microtubules. As a complement and for a comparison, we have included also tau-tau complex structures, including cryo-EM structures of tau filaments isolated from brain of individuals who died of a tauopathy. Until April 2021, 76 structures containing tau sequence were deposited in
PDB. 42 were obtained by X-ray crystallography, 25 with electron microscopy, 5 with solution NMR and 4 with electron crystallography (overview of selected structural depositions is presented in Tables 1 and 2). An ensemble of 995 conformations of tau microtubule binding domain is deposited in the protein ensemble database (Lazar et al. 2021) under ID PED00017 (Ozenne et al. 2012). Relative positions of tau peptides observed in complexes with antibody Fab fragments along the 2N4R tau isoform are shown on Figure 1. In the following the tau global fold as well as partial structures will be discussed.

\section{Global conformations of tau protein}

NMR measurements with full length tau molecule have revealed preferences of short tau segments for transient secondary structures - $a$-helices (tau residue stretches 114123, 428-437), polyproline II helices (175-184, 216-223, 232-239) and $\beta$-sheets (86-92, 161-166, 224-230, 274-284, $305-315,336-345)$ and the global folding was probed by PRE (Mukrasch et al. 2009; Melkova et al. 2019). By ensemble FRET measurements the C-terminus was shown to be present with high frequency in the proximity of MTBD and $40 \mathrm{~N}$-terminal tau residues, which was termed as the "paperclip" model of tau conformation (Jeganathan et al. 2006). More recently, by single-molecule FRET measurements an

Table 2. Tau structures obtained by NMR and cryo-EM

\begin{tabular}{|c|c|c|c|}
\hline \multicolumn{4}{|c|}{ Solution NMR } \\
\hline PDB ID & Binding partner & Tau peptide used & \\
\hline $1 \mathrm{I} 8 \mathrm{H}$ & Pin1 WW (Wintjens et al. 2001) & ${ }^{225}{ }^{K V S V V R p T P P K S P S}{ }^{237}$ * & \\
\hline $5 \mathrm{NVB}$ & F-actin (Fontela et al. 2017) & ${ }^{254}$ KNVKSKIGSTENLKH ${ }^{268}$ & \\
\hline $5 \mathrm{~N} 5 \mathrm{~A}$ & F-actin (Fontela et al. 2017) & $\operatorname{Tau}(254-290)$ & \\
\hline $5 \mathrm{~N} 5 \mathrm{~B}$ & F-actin (Fontela et al. 2017) & $\operatorname{Tau}(292-319)$ & \\
\hline 2MZ7 & Microtubules (Kadavath et al. 2015) & $\operatorname{Tau}(267-312)$ & \\
\hline \multicolumn{4}{|c|}{ Cryo-EM } \\
\hline & Binding partner & Tau peptide modelled & Resolution $(\AA)$ \\
\hline $6 \mathrm{CVJ}$ & Microtubules (Kellogg et al. 2018) & ${ }^{256}{ }^{2}$ VKSKIGSTENLK ${ }^{267}$ (Fig. 2S) & 3.20 \\
\hline $6 \mathrm{CVN}$ & Microtubules (Kellogg et al. 2018) & K274-V300 (Fig. 2V) & 3.90 \\
\hline \multicolumn{4}{|c|}{ Tauopathy and in vitro aggregated filaments } \\
\hline & Filament source and type & Tau peptide modelled & Resolution $(\AA)$ \\
\hline $5 \mathrm{O} 3 \mathrm{~L}$ & AD PHF (3R+4R) (Fitzpatrick et al. 2017) & V306-F378 & 3.40 \\
\hline 6HRE & AD PHF sporadic (3R+4R) (Falcon et al. 2018b) & ${ }^{273} \mathrm{GK}^{274} /{ }^{304} \mathrm{GS}^{305}$-E380 ** (Fig. 3A) & 3.20 \\
\hline 6NWP & CTE type I filament (3R+4R) (Falcon et al. 2019) & $\mathrm{K} 274 / \mathrm{S} 305-\mathrm{R} 379^{* *}$ & 2.30 \\
\hline $6 \mathrm{GX} 5$ & Picks disease (3R) (Falcon et al. 2018a) & K254-F378*** (Fig. 3B) & 3.20 \\
\hline 6TJX & CBD type II (4R) (Zhang et al. 2020) & K274-E380 (Fig. 3C) & 3.00 \\
\hline 6QJH & $\begin{array}{l}\text { In vitro aggregated 2N4R (snake filaments) (Zhang et al. } \\
2019 \text { ) }\end{array}$ & G272-H330 (Fig. 3D) & 3.30 \\
\hline 6QJQ & In vitro aggregated 2N3R (Zhang et al. 2019) & G272-H330*** (Fig. 3E) & 3.70 \\
\hline
\end{tabular}

* Tau phospho-peptide contains S227 instead of A present in tau sequence, ${ }^{* *} 3 \mathrm{R}$ tau incorporated in the fibril has sequence GKVQIVYK, and 4R tau GSVQIVYK at the N-terminal part of the ordered core, ${ }^{\star * \star} 3 \mathrm{R}$ tau isoforms lack residues 275-305 (numbering according human longest full length isoform $2 \mathrm{~N} 4 \mathrm{R}$. 
S-shaped model has been obtained, with both termini more far apart from each other than from MTBD (Elbaum-Garfinkle and Rhoades 2012). Ion mobility mass spectrometry measurements have shown the presence of highly unfolded as well as folded conformers, but with the latter forming only $2 \%$ of the total population (Jebarupa et al. 2018). These minority globular and folded conformers of full-length tau were recently modelled by crosslinking-guided discrete MD simulations (Popov et al. 2019). Fluorescence anisotropy measurements with the use of anti-Brownian electrokinetic trap have also shown two families of tau conformations (Manger et al. 2017).

\section{Projection domain of tau}

Monoclonal antibody IPN002 recognises an epitope on the extreme N-terminus of tau. IPN002 was humanized to Gosuranemab (BIIB092), an IgG4 antibody, which inhibited tau seeding activity from brain homogenates and transgenic mouse interstitial fluid in cell models. However, it has failed to demonstrate clinical efficacy in progressive supranuclear palsy (PSP) trial and is currently being tested as an AD therapy. The antibody IPN002 was crystallized with tau $9-26$ peptide and the tau sequence ${ }^{15}$ AGTYGLGD $^{22}$ can be found in the complex structure. The tau peptide forms a type I $\beta$-turn between residues $16-19$, with one hydrogen bond formed between the carbonyl oxygen of G16 and the amide nitrogen of G19, which is further stabilized by one additional hydrogen bond formed between residues A15 and G21 (Fig. 2A) (Sopko et al. 2020). Residue Y18 can be phosphorylated and in the phosphorylated form interacts with $\mathrm{SH} 2$ domain of tyrosine Fyn kinase, which induces tau trafficking to detergent-resistant membrane microdomains (Usardi et al. 2011).

Peptide tau26-44 was proposed as a minimal biologically active moiety of longer $20-22 \mathrm{kDa}$ truncated neurotoxic tau fragment tau26-230 that is accumulating in vivo at $\mathrm{AD}$ presynaptic terminals and is present in cerebrospinal fluid (CSF) from AD patients (peptide A in Fig. 1; Borreca et al. 2018). Perini and colleagues have performed five $30 \mathrm{~ns} \mathrm{long}$ molecular dynamics simulations starting from different initial conformations generated by I-TASSER (Yang et al. 2015). The same procedure has been performed for a control peptide with reverse amino acid sequence. Both peptides obtained mainly coil like structures, turns and bends. Temporary isolated $\beta$-bridges, $\alpha$-helices and $3{ }_{10}$-helices were also detected (Perini et al. 2019). SAXS curves were also measured for studied peptides and the ensemble of conformations that give the best fit to the experimental data were extracted from $\mathrm{MD}$ runs. The ensemble optimization method EOM with the genetic algorithm GAJOE was used (Bernado et al. 2007). The control peptide was found to exhibit a more compact folding than the tau26-44 peptide.
Structure of tau peptide ${ }^{57}$ EEPGSETSDAKST ${ }^{69}$ from the first $\mathrm{N}$-terminal insert was solved in the complex with antibody CBTAU28.1 Fab (Apetri et al. 2018). Tau peptide forms an $\alpha$-helix between residues P59 and K67 (Fig. 2B) which is consistent with observed $5 \%$ a-helical conformation of this region in the ensembles selected by the ASTEROIDS analysis of NMR chemical shifts (Schwalbe et al. 2014; Melkova et al. 2019).

\section{Proline-rich region}

Antibody AT8 (Mercken et al. 1992), relevant for staging of AD progression (Braak et al. 2006), was investigated by $\mathrm{X}$-ray crystallography and also by the combination of NMR and MD in its free solution form. Interestingly, AT8 recognizes multiple phosphorylated sites in the region 199-208. The epitope was originally mapped by ELISA to double phosphorylated peptide pS202/pT205 with cross-reactivity to phospho-pattern pS199/pS202 (Porzig et al. 2007). By surface plasmon resonance (SPR), the highest affinity similar to that of PHF-tau was shown for triple phosphorylated tau peptide with phosphorylated residues pS202/pT205/pS208. Phosphorylation pattern was evaluated on 20 amino acid long tau peptides spanning tau residues 195-214. Peptide with phosphorylated residues pS199/pS202/pT205 showed 10 times lower affinity than pS202/pT205/pS208 and the double phosphorylated peptide (pS202/pT205) showed 27.6 times lower affinity (Malia et al. 2016). AT8 epitope peptide was found in a partially extended conformation with some occurrence of polyproline type II helix secondary structure (Fig. 2C). Combined NMR and MD study proposed an existence of a turn conformation on the C-terminus of AT8 epitope, where the sidechain of pT205 flips between interaction with amide proton of G207 and with sidechain of R209 (Fig. 2U) (Gandhi et al. 2015). The NMR spectrum of tau peptide tau192-212 (peptide B in Fig. 1; pS202/pT205) has reproduced well that of phosphorylated full length tau protein. The full-length tau and tau fragment TauF5 (tau165-224) were in vitro phosphorylated using recombinant $\mathrm{CDK} 2 / \mathrm{CycA} 3$ kinase.

\section{Interaction site of tau with 14-3-3 proteins}

Tau residue pS214 is involved in the interaction of tau with 14-3-3 proteins together with pS324 from MTBD (Joo et al. 2015). The 14-3-3 protein family comprises seven isoforms; they exist as homo- or heterodimers and interact mainly with phosphorylated protein partners. 14-3-3 $\sigma$ was shown to be involved in tubulin stability and neuritic outgrowth in neurons. Tau peptides ${ }^{211} \mathrm{RTP}^{2}$ SLPTP ${ }^{218}$ and ${ }^{323} \mathrm{GpSLG}^{326}$ were observed in complexes with 14-3-3 $\sigma$ protein (Fig. 2Q, $2 \mathrm{R})$. The peptides are bound in an extended conformation in the central binding channel of 14-3-3 $\sigma$ monomer. The full 
A

B

C

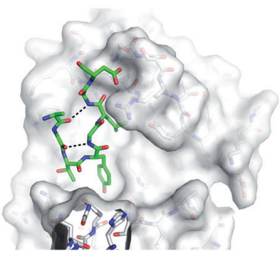

E

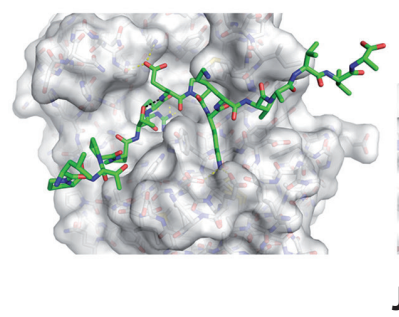

F
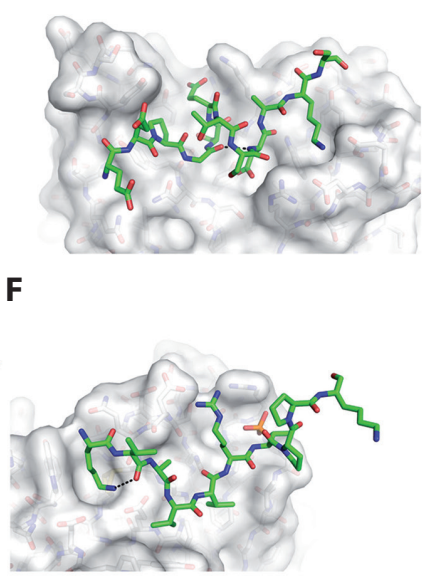

J
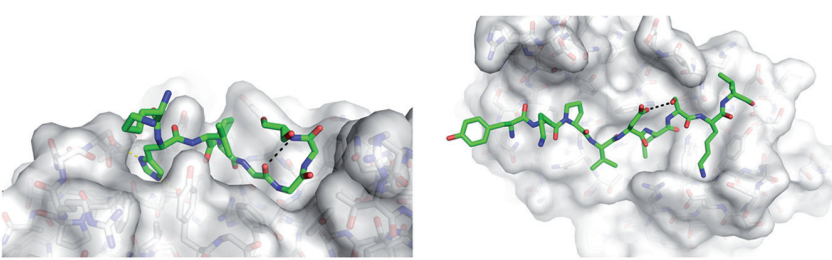

N

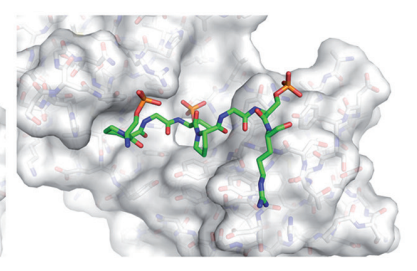

G

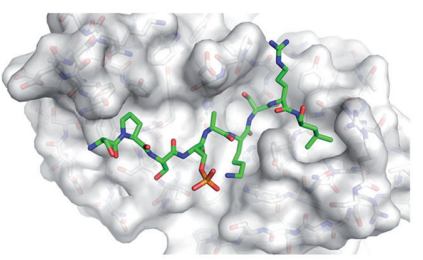

K

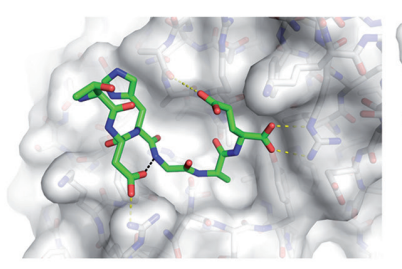

D

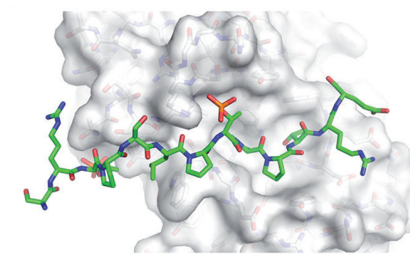

H

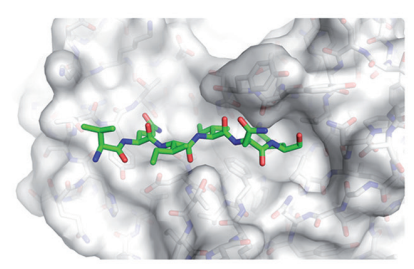

L

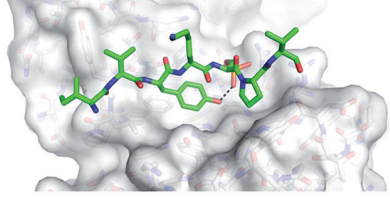

P

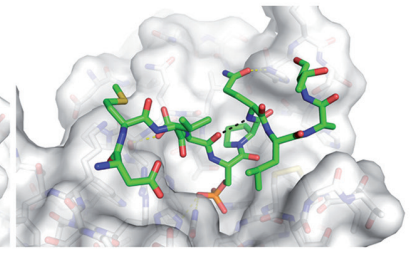

$\mathbf{T}$

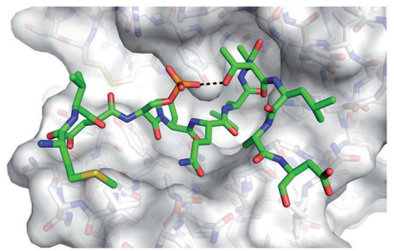

W

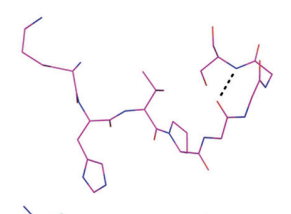

V
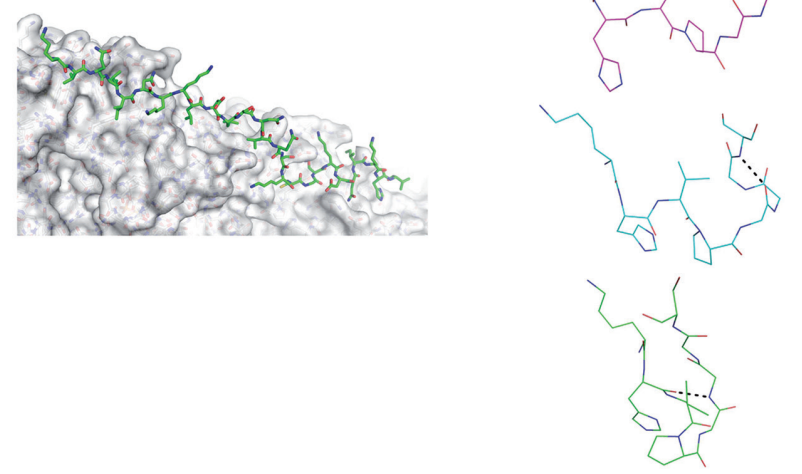
length phosphorylated tau protein binds to $14-3-3 \sigma$ dimer through both mentioned phosphosites forming a complex with 2:1 stoichiometry (14-3-3б:tau) (Neves et al. 2021). The tau peptide with pS214 was the basis for the construction of chimeric inhibitors of $14-3-3 \sigma /$ tau interaction that were composed of tau sequence with organic scaffolds fused to residue $\mathrm{T} 217$ extending the binding of the inhibitor also to the proximal fusicoccin (14-3-3 $\sigma$ stabilizer) binding site (Milroy et al. 2015).

Phospho-specific antibody PT3 that binds tau phosphorylated at threonine residues 212 and 217 has been generated and was reported to bind AD PHF and phosphorylated recombinant tau with picomolar affinity (Van Kolen et al. 2020). The whole tau peptide ${ }^{210}$ SRpTPSLPpTPPTRE ${ }^{222}$ used for co-crystallization (with acetylated N-terminus) could be modelled in the complex structure. Tau phosphopeptide has an extended conformation with polyproline II helix character and contains intramolecular hydrophobic contacts (Fig. 2D).

pT217 epitope can be used as an AD biomarker in an immunoassay to distinguish $\mathrm{AD}$ cases from other dementia cases and healthy controls (Hanes et al. 2020).

\section{Tau sequence 210-230 interacting with BIN1 and tau5 antibody}

It was shown that tau interacts with C-terminal SH3 domain of BIN1 (Bridging integrator-1) through its sequence 210-240 (Sottejeau et al. 2015). BIN1 gene was the first of the genetic determinants for sporadic AD with a clear link to Tau pathology (Chapuis et al. 2013). The model of the complex structure of $\mathrm{SH} 3$ domain of BIN1 isoform 1 and tau peptide was obtained with docking using HADDOCK (van Zundert et al. 2016) that was driven under defined intermolecular unambiguous restraints from a NOESY spectrum and ambiguous restraints chosen as the residues involved in intermolecular NOEs. Tau peptide 213-229 has been modelled (Lasorsa et al. 2018). The ${ }^{216} \mathrm{PxxP}^{219}$ consensus motif of Tau peptide is bound into the canonical hydrophobic $\mathrm{xP}$ binding pocket of the $\mathrm{SH} 3$ domain. The positively charged tau residues R 221 and K224 interact with negatively charged residues in the n-Src loop of the specificity zone of BIN1 SH3.

The conformation of tau peptide ${ }^{215}$ LPTPPTREPKKVAVVR $^{230}$ can be obtained from its complex with Tau5 antibody Fab. Its conformation is stabilized by a T-turn motif in the central part of tau epitope, where side chain oxygen of T220 makes a hydrogen bond with main chain amid of E222 (Fig. 2E). This intrachain hydrogen bond stabilizes a V shaped conformation of the peptide (Cehlar et al. 2015).

Sequence stretch ${ }^{225}$ KVAVVRT $^{231}$ may be contributing to the formation of PHF and also to microtubule binding. It loses its flexibility measured by solid state NMR upon in vitro filament formation (Savastano et al. 2020). It was shown that regions flanking MTBD, including this segment, are required for high affinity binding of tau to microtubules (Mukrasch et al. 2007).

\section{Tau conformations around phosphorylated residue T231}

The tau conformation around residue $\mathrm{T} 231$, recognized also by an antibody AT180 used for defining an AD pathological form of phospho-tau, was analysed by several approaches and also by an ultra-specific avian antibody recognizing epitope around pT231. The bond between pT231-P232 is amenable for cis-trans isomerization by peptidyl-prolyl isomerase Pin1, where the cis conformation was shown to appear early in the brains of humans with mild cognitive impairment (Nakamura et al. 2012). NMR measurements performed with tau fragment tau208-324 showed that all prolines were for over $90 \%$ in the trans conformation (Ahuja et al. 2016). Lyons and co-workers have performed MD simulations of differently phosphorylated tau peptide 225250 (peptide $\mathrm{C}$ in Fig. 1) under various conditions (ionic power, phosphate charge) and showed that phosphorylation disrupts the $\beta$-sheet patterns present at $\mathrm{N}$ - and $\mathrm{C}$ - termini of non-phosphorylated peptide. The double phosphorylation has stabilized formation of a transient $\alpha$-helix between

4 Figure 2. Structures of tau peptides bound to antibody Fab fragments, 14-3-3 $\sigma$ and microtubules. Structure of tau peptide is shown as sticks with green carbon atoms. Structural poses were drawn from PDB depositions with codes: 6PXR, IPN002 Fab with tau A15-D22 (A); 5ZV3, CBTAU-28.1 with tau E57-S68 (B); 5E2W, AT8 Fab with tau pS202-R209 (C); 6XLI, PT3 Fab with tau S210-E222 (D); 4TQE, Tau5 Fab with tau L215-R230 (E); 4GLR, avian antibody Fab with tau K225-K234 (F); 5ZIA, CBTAU-24.1 with tau S235-L243 (G); 6LRA, Tau2r3 Fab with tau V275-K280 (H); 5MO3, DC8E8 Fab with tau K298-S305 (I); 6DCW, CBTAU-27.1 Fab with tau Y310-V318 (J); 2V17, MN423 Fab with tau T386-E391 (K); 6BB4, C5.2 Fab with tau I392-V398 (L); 6DCA, 6b2 Fab with tau T403-L408 (M); 6DC8, 8b2 fab with tau S404-L408 (N); 6DC9, h4E6 fab with tau T403-L408 (O); 6H06, CBTAU-22.1 Fab with tau D418-T427 (P); 4FL5, 14-3-3 $\sigma$ with tau R211-P218 (Q); 5BTV, 14-3-3 $\sigma$ with tau G323-G326 (R); 6CVJ, microtubule with tau V256-K267 (S); 5DMG, Rb86 fab with tau M419-L428 (T); snapshot of the double phosphorylated tau peptide (pS202pT205) from MD simulation (Gandhi et al. 2015; top), aligned conformations of double (pS202pT205) and triple (pS202pT205pS208) phosphorylated tau peptides from complexes with AT8 antibody (Malia et al. 2016; bottom) (U); 6CVN, microtubule with tau K274-V300 (V); Line model of tau segment ${ }^{298}$ KHVPGGGS $^{305}$ from the complex with DC8E8 antibody (5MO3, top) and NMR conformations of tau peptide bound to microtubules (2MZ7; state 1, middle; state 2, bottom) (W). Pymol version 1.8.2.1 was used for preparation of structural figures. 
residues A239-T245 (Lyons et al. 2014) that was observed previously by NMR on phosphorylated TauF4 (208-324) fragment (Sibille et al. 2012). Molecular ensembles were calculated based on NMR data for non-phosphorylated, doubly phosphorylated (T231/S235) and tetra- phosphorylated (T231/S235/237/238) tau peptide 225-246 (Schwalbe et al. 2015) and found that phosphorylation of T231 resulted in the formation of a salt bridge between the phosphate group of T231 and the neighbouring basic side chain of R230. The structure of tau peptide ${ }^{225}$ KVAVVRpTPPK $^{234}$ from the complex with avian antibody was solved. Tau phospho-peptide adopts a conformation with two sharp turns at V228 and pT231 (Fig. 2F). This conformation is stabilized by an intramolecular hydrogen bond between the side chain nitrogen of K225 and the carbonyl oxygen of V226 (Shih et al. 2012).

The conformation of a phospho-peptide with pS238 was solved in complex with phosphorylation independent antibody CBTAU24.1 (the phosphate group points away from the paratope). The peptide adopts an extended conformation with a sharp turn from A239 to L243 where only the side chain nitrogen of K240 is able to form intramolecular hydrogen bonds (Fig. 2G) (Zhang et al. 2018).

\section{Microtubule binding domain}

Two-dimensional Nuclear Overhauser Effect (NOE) spectra in the absence and presence of MTs were recorded for peptide tau267-312 (Kadavath et al. 2015). The calculations with medium and long range contact data (1.8-6.0 $\mathrm{A}$ ) of MT bound conformations yielded converged hairpin conformations for residues 269-284 and 300-310. The hairpin turn is formed by PGGG motifs and is followed by an extended structure of aggregation-prone hexapeptides ${ }^{275}$ VQIINK ${ }^{280}$ and ${ }^{306}$ VQIVYK ${ }^{311}$. The calculation for the peptide in solution did not converge to one major conformer.

One of the lowest energy MT-bound conformers stored in PDB shows a similar $\beta$-turn stabilized by a main chain hydrogen bond between G302 and S305 as a tau peptide from the complex with DC8E8 antibody (Fig. 2I,W) (Skrabana et al. 2017). Antibody DC8E8 recognizes truncated tau proteins preferentially to the full length tau proteins, inhibits tau aggregation (Kontsekova et al. 2014b), inhibits internalization of extracellular tau by neurons (Weisova et al. 2019), and its epitope in R2 is the basis for the active AD vaccine (Kontsekova et al. 2014a; Novak et al. 2017). DC8E8 binds tau sequence motif HXPGGG present in each of its four MTBRs.

The conformations of tau segment from R2-R3 interface (295-311, peptide D in Fig. 1) were probed by molecular dynamics, Rosetta modelling (Ovchinnikov et al. 2018) and experimental methods that showed formation of meta- stable compact structures between ${ }^{306} \mathrm{VQIVYK}^{311}$ and its upstream sequence modulating aggregation propensity, where destabilization of a $\beta$-hairpin conformation leads to the aggregation-prone conformation with exposed amyloid forming motif (Chen et al. 2019).

Antibody CBTAU27.1 has a common germline origin with the N-terminal antibody CBTAU28.1 (Apetri et al. 2018). It recognizes epitope ${ }^{310}{ }^{\text {YKPVDLSKV }}{ }^{318}$ in R3 bordering the PHF6 aggregation prone hexapeptide ${ }^{306}{ }^{2}$ IVYK $^{311}$. The tau peptide has mainly straight conformation with possible interaction of sidechains of residues D314 and S316 (Fig. 2J).

It was shown by NMR spectroscopy that tau uses several short helical segments for binding to actin (Fontela et al. 2017). a-helical or 310 -helical conformations were identified for tau segments 261-268, 277-283 and 315-318.

Structures of sequences from R1 ( ${ }^{256}$ VKSKIGSTEN$\mathrm{LK}^{267}$, Fig. 2S), and R2 (274-300, whole R2 sequence without PGGG, Fig. 2V) bound to the MT surface in extended conformation were obtained using cryo-EM and Rosetta modelling. Tau synthetic construct with four copies of either R1 or R2 replacing the regular MTBD were used to obtain a better resolution (Kellogg et al. 2018). The ensemble of tau region 202-395 bound to microtubule has been obtained using meta inference cryo-electron microscopy (Brotzakis et al. 2020).

The binding of tau peptide from $\mathrm{R}^{\prime}$ region to a-tubulin surface has been proved with INPHARMA NMR method (interligand nuclear Overhauser effect (NOE) for pharmacophore mapping). Tau peptide corresponding to residues 368-402 has been used (Kadavath et al. 2018).

\section{From peptide steric zippers to tauopathy filaments}

It has been shown that short tau peptides containing sequences ${ }^{275}$ VQIINK ${ }^{280}$ or ${ }^{306}$ VQIVYK ${ }^{311}$ can form fibrillar aggregates (von Bergen et al. 2000, 2001). These tau peptide segments have been crystalized in form of peptide filaments which enabled their structure solution. Nanocrystals from peptides VQIINK and KVQIINKKLD were prepared and the structures of fibrils were determined by electron crystallography (Seidler et al. 2018). Peptides form homosteric zippers (formed by a single sequence) and they are more tightly bound than previously reported VQIVYK zippers (Sawaya et al. 2007; Fig. 3F), because they have higher shape complementarity and burry larger surface areas. Interestingly, tau $\mathrm{K} 18$ construct with ${ }^{309} \mathrm{VY}^{310}$ mutated to IN, thus containing two VQIINK segments, aggregated faster than the wild type construct. Based on the side chain interface between the $\beta$-sheets, fibril-capping inhibitors have been generated that were able to inhibit both tau aggregation and the seeding effect of exogenous fibrils (Sievers et al. 2011; Seidler et al. 2018, 2019). 
A

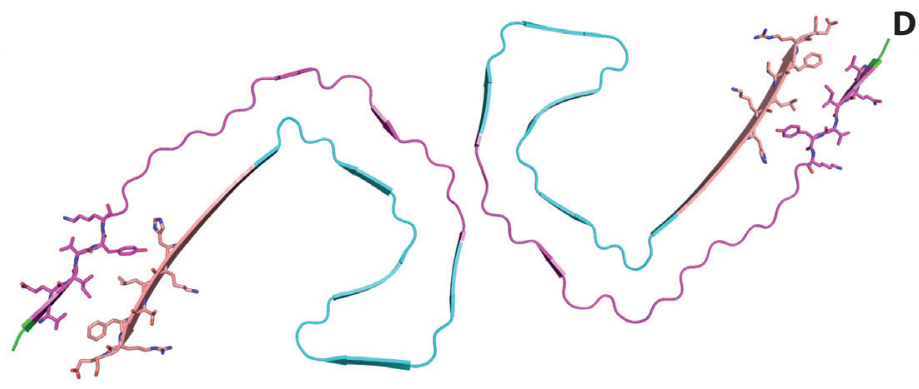

B

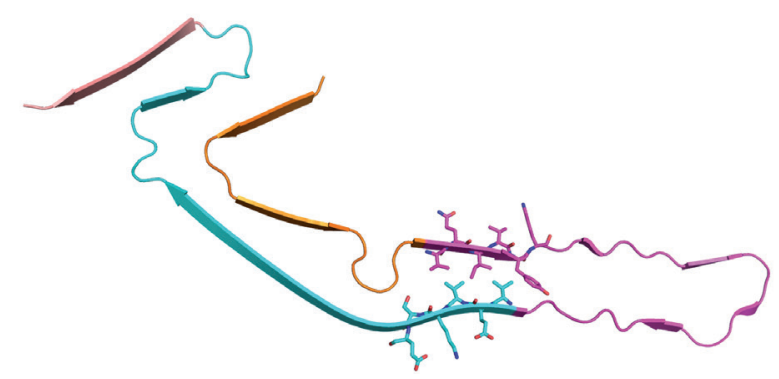

C

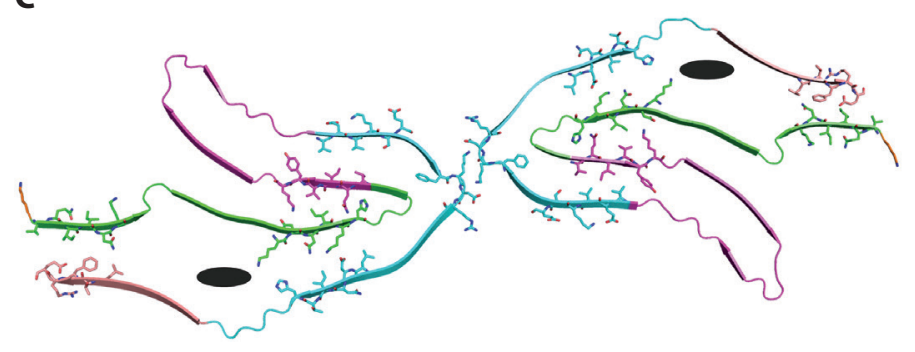

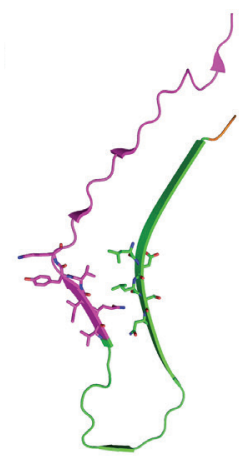

E

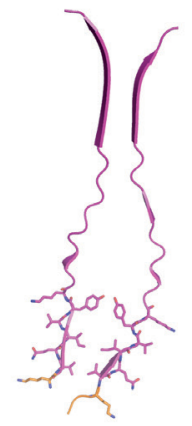

$\mathbf{F}$

Figure 3. Tau filaments and steric zippers. A. AD PHF fold. Zipper interface residues ${ }^{306} \mathrm{VQIVYK}^{311}$ and ${ }^{374}{ }^{\text {HKLTFRE }}{ }^{380}$ are shown as sticks. Colored according tau MTBRs, R1 orange, R2 green, R3 magenta, R4 cyan, R' salmon. B. Picks narrow fold. Zipper interface residues ${ }^{306}$ VQIVYK $^{311}$ and ${ }^{337}$ VEVKSE $^{342}$ are shown as sticks. C. CBD type II (wide) tau fold with sidechains forming four layer interface $\left({ }^{337}\right.$ VEVKSE $^{342},{ }^{306}$ VQIVYK $^{311}$, ${ }^{294} \mathrm{KDNIKH}^{299},{ }^{357} \mathrm{LDNITH}^{362}$ ) shown as sticks. Zipper interface of ${ }^{275}$ VQIINK ${ }^{280}$ with ${ }^{376}$ LTFRE $^{380}$ is also shown as sticks. Interprotofilament interfaceforming segment ${ }^{346} \mathrm{FKDR}^{349}$ is shown as sticks. PDB 6VH7. Non-proteinaceous density is depicted as black ellipse. D. Fold of in vitro heparin induced $2 \mathrm{~N} 4 \mathrm{R}$ filament (snake filament). Zipper interface between ${ }^{306}$ VQIVYK $^{311}$ and ${ }^{282}$ LDLSN $^{286}$ is shown as sticks. E. Fold of in vitro heparin induced 2N3R filament with ${ }^{306}$ VQIVYK ${ }^{311}$ interface. F. VQIINK steric zipper interface from protein microcrystal (PDB 5V5C).

Tau peptide VQIINK can be also found in a complex structure with antibody 2r3 Fab (Fig. 2H), generated by immunization with tau peptide 272-283 and inhibiting tau aggregation (Tsuchida et al. 2020).

The above-mentioned interfaces created by short peptides were not observed in cryo EM structures of tau filaments isolated from patients with $\mathrm{AD}$, Picks disease (PiD), corticobasal degeneration (CBD) and chronic traumatic encephalopathy (CTE) (Lippens and Gigant 2019; Scheres et al. 2020). VQIVYK forms a heterosteric zipper interface with corresponding sequence VEVKSE from R4 in PiD and CBD folds (Fig. 3). In AD and CTE folds, VQIVYK forms an interface with tau sequence ${ }^{375} \mathrm{KLTF}^{378}$ from R'. Homosteric but parallel interface of VQIVYK was observed only for the in vitro heparin-induced $3 \mathrm{R}$ filaments, which ordered core is composed of parallel parts of R3 from two tau molecules (Fig. 3E). The folds of in vitro aggregated tau filaments differ markedly from patient-derived filament folds. Heparin induced 2N4R and 2N3R tau filaments were characterized by cryo-EM (Zhang et al. 2019) and 0N4R filaments by solid state NMR (Dregni et al. 2019). 2N4R tau was shown to form four filament types and three of them were solved (snake, twister and jagged filament) to have a core with kinked hairpin fold with stabilized R2 and part of R3 (Fig. 3D, snake filament). In AD and CTE folds, tauopathies with both 3R and $4 \mathrm{R}$ tau proteins involved in filaments, repeats R3, R4 and part of R' are stabilized in C-shaped double layered rigid fibril core composed of eight $\beta$-sheets with $\beta$-helix configuration of chain turn (Fig. 3A) (Fitzpatrick et al. 2017; Falcon et al. 2018 b). PiD fold, a 3R tauopathy, consists of nine $\beta$-sheets, of which the first and last two create a three-layered motif. The rest of a J-shaped fold contains two layers (Fig. 3B). Residues K254-F378 are stabilized (Falcon et al. 2018a). A 4R tauopathy, CBD, is characterized by compact four-layered fold that extends from K274 to E380. It stabilizes the last residue of R1, repeats R2-R4 and 12 residues form R' (Fig. 3C). In CTE and CBD folds, a channel of non-proteinaceous density has been observed (Falcon et al. 2019; Zhang et 


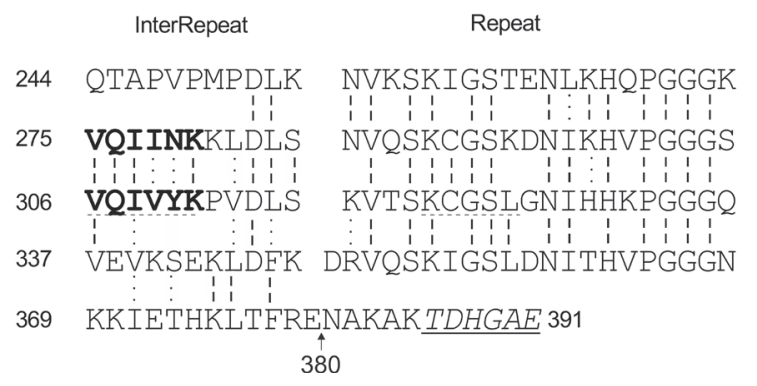

$\mathrm{R} 1$

$\mathrm{R} 2$

R3

\section{R4}

$\mathrm{R}^{\prime}$

Figure 4. Amino acid sequence of tau MTBD. Conserved and similar amino acids between repeats are shown with dashed and dotted lines respectively. Crystalized epitope of antibody MN423 is underlined and tau stretches contributing to its binding are dashed underlined. Aggregation prone hexapeptides at the beginning of R2 $\left(\mathrm{PHF}^{*}\right.$ ) and R3 (PHF6) are shown in bold. The position of E380, where the recently obtained cryo-EM PHF core structure ends is shown with an arrow.

al. 2020). The mentioned folds are composed of relatively conserved $\beta$-sheets arranged differently due to the diversity provided by the loop regions.

Site-specific ubiquitination could be mapped on the models of $\mathrm{AD}$ and $\mathrm{CBD}$ filaments that can modulate fibril subpopulations (Arakhamia et al. 2020). The binding sites on AD PHFs and SFs for tau PET ligand APN-1607 have been investigated with three possible sites identified, two in $\beta$-helix of PHFs and SFs and one in the C-shaped cavity of SFs (Shi et al. 2021).

The tau dimer in an $\mathrm{AD}$ fold of $\mathrm{R} 3$ and $\mathrm{R} 4$ (peptides stacked vertically) has been used as a starting conformation for replica-exchange MD simulations in explicit solvent in order to address its conformational ensemble because the dimer formation may be an important step in filament formation (peptide E in Fig. 1). Tau dimer explored elongated, U-shaped, V-shaped and globular conformations (Derreumaux et al. 2020). The effect of S356 phosphorylation has been also evaluated.

Conformational antibody MN423 has been prepared as an imprint of the core of AD PHF (Novak et al. 1991). In the complex structure with MN423 Fab, tau peptide ${ }^{386} \mathrm{TDH}$ GAE $^{391}$ can be observed (Sevcik et al. 2007). MN423 binds only tau proteins truncated at E391. In addition to its crystalized tau epitope, tau sequence stretches ${ }^{306}$ VQIVYK $^{311}$ and ${ }^{321} \mathrm{KCGSL}^{325}$ were shown to contribute to MN423-tau interaction (Skrabana et al. 2004; Fig. 4). Sidechain of D387 forms a hydrogen bond with main chain nitrogen of G389 that creates an Asp-turn motif (Fig. 2K).

\section{C-terminal domain}

Phosphorylated amino acids in the C-terminal domain of tau protein (pS396, pS404, pS413, pS422) are currently be- ing tested as targets of passive and active immunotherapy (Li and Gotz 2017).

Tau peptide ${ }^{392}$ IVYKpSP ${ }^{397}$ can be found in complex with antibody C5.2 (Chukwu et al. 2018). The strong interaction between phosphate group and sidechain of Y394 (2.5 ^̊ distance) locks the tau sequence ${ }^{394} \mathrm{YKpS}^{396}$ in a $\beta$-strand conformation (Fig. 2L). CDR H3 of the antibody forms a "nest" for phosphoserine recognition.

Antibodies 8B2, 6B2 and 4E6 generated by the immunization with the tau peptide 386-408 containing the pS396/ pS404 motif were structurally characterized (Chukwu et al. 2019). Antibodies 6B2 and 4E6 were previously shown to be of different specificity and affinity. Administration of 4E6 to htau mice showed improved cognition and reduced soluble phospho-tau, whereas $6 \mathrm{~B} 2$ was ineffective, despite it has shown higher affinities. 4E6 have also reduced tau spreading between neurons measured in microfluidic chamber (Congdon et al. 2016). All three antibodies bind well the peptides containing pSer404 and both pSer396/pSer404, but they differ in binding the pSer396 containing peptide. This peptide is bound well only by the antibody $6 \mathrm{~B} 2$, whereas the antibody $8 \mathrm{~B} 2$ binds this peptide only at high concentrations and antibody h4E6, a humanized version of 4E6, does not recognize this peptide at all.

Only the antibody h4E6 was successfully crystallized with peptide containing phosphorylated S404. Tau peptide bound to antibody 8B2 $\left({ }^{404} \mathrm{SPRHL}^{408}\right)$ has a straight linear conformation with a small bend between residues R406 and $\mathrm{H} 407$ (Fig. 2 N). Tau peptide ${ }^{403}$ TSPRHL $^{408}$ can be observed in complex with antibody 6B2. The C-terminus of tau peptide forms a half helical turn in contrast to the straight conformation seen in the $8 \mathrm{~B} 2$ complex (Fig. $2 \mathrm{M}$ ). The conformation of tau peptide ${ }^{403} \mathrm{TpSPRHL}^{408}$ in complex with antibody h4E6 is similar to that bound to $8 \mathrm{~B} 2$ but with a bigger backbone bend. Residue pS404 has a different orientation relative to the antibody $\mathrm{H}$ and L chains as $\mathrm{S} 404$ in other two antibody complexes (Fig. 2O). In h4E6 complex it points to the antibody heavy chain, which creates a slight helical twist in peptide conformation in the opposite direction as seen in $6 \mathrm{~B} 2$ (Chukwu et al. 2019).

Tau peptide ${ }^{419}$ MVDPSPQLATL ${ }^{428}$ can be found in complex with a rabbit antibody Rb86 Fab (Bujotzek et al. 2016). Interestingly, the backbone conformation around pS422 is similar to that of peptide with pS404 in complex with h4E6 (backbone RMSD of segments ${ }^{403} \mathrm{TpSPR}^{406}$ and ${ }^{421} \mathrm{DpSPQ}^{424}$ is $0.28 \AA$ ). Sidechain of residue T427 makes a hydrogen bond with the phosphate group of pS422, creating a turn conformation in the C-terminal part of tau epitope (Fig. 2P).

Conformation of similar tau peptide ${ }^{418}$ DMVDpSPQ$\mathrm{LA}^{426}$ was solved in complex with antibody CBTAU22.1 Fab (van Ameijde et al. 2018). In contrast to the binding of 
tau phosphopeptide by Rb86, the phosphate group in the complex with CBTAU22.1 is buried in the cavity formed between the antibody heavy and light chains. Tau peptide forms a helical conformation between residues D421 and L425 stabilized by main chain hydrogen bonds (Fig. 2T).

The a-helical conformation was observed for the tau C-terminal peptide 423-441 in TFE containing solution ( $\alpha$-helix spanning residues $426-439$ ) by NMR spectroscopy (Esposito et al. 2000) which is consistent with the data from the NMR measurement with full length tau molecule that showed helical preference for tau C-terminal stretch ${ }^{428}$ LADEVSASLA $^{437}$ (Mukrasch et al. 2009).

\section{Conclusions and perspectives}

Some conformational preferences observed for the various regions of full-length tau molecule in solution are preserved in the bound conformations of tau in complexes with antibodies, where also local hydrogen bonding stabilizing specific conformations can be observed. Efforts to elucidate aggregation-prone conformation of truncated tau proteins (Kovacech and Novak 2010) or aggregation resistant/inert tau conformations (Walker et al. 2012; Mirbaha et al. 2018) may be an important direction for the future research designing molecules for identification, inhibition or stabilization of these conformational states. Structural characterization of unstable tau oligomeric states that may represent toxic intermediates on the fibril formation pathway is also needed (Fandrich 2012; Nguyen et al. 2021).

Conflicts of interest. Authors declare no conflict of interest.

Acknowledgments. This work was supported by the VEGA grant numbers 2/0145/19 and 02/0163/19. We thank to Dr. Neha S. Gandhi for sharing peptide structure snapshots.

\section{References}

Ahuja P, Cantrelle FX, Huvent I, Hanoulle X, Lopez J, Smet C, Wieruszeski JM, Landrieu I, Lippens G (2016): Proline conformation in a functional tau fragment. J. Mol. Biol. 428, 79-91 https://doi.org/10.1016/j.jmb.2015.11.023

Apetri A, Crespo R, Juraszek J, Pascual G, Janson R, Zhu XY, Zhang H, Keogh E, Holland T, Wadia J, et al. (2018): A common antigenic motif recognized by naturally occurring human $\mathrm{V}(\mathrm{H}) 5$ $51 / \mathrm{V}(\mathrm{L}) 4-1$ anti-tau antibodies with distinct functionalities. Acta Neuropathol. Commun. 6, 43 https://doi.org/10.1186/s40478-018-0543-z

Arakhamia T, Lee CE, Carlomagno Y, Duong DM, Kundinger S.R, Wang K, Williams D, DeTure M, Dickson DW, Cook CN, et al. (2020): Posttranslational modifications mediate the structural diversity of tauopathy strains. Cell 180, 633-644 e612 https://doi.org/10.1016/j.cell.2020.01.027

Baggett DW, Nath A (2018): The rational discovery of a tau aggregation inhibitor. Biochemistry 57, 6099-6107 https://doi.org/10.1021/acs.biochem.8b00581

Bernado P, Mylonas E, Petoukhov MV, Blackledge M, Svergun DI (2007): Structural characterization of flexible proteins using small-angle X-ray scattering. J. Am. Chem. Soc. 129, 5656-5664 https://doi.org/10.1021/ja069124n

Borreca A, Latina V, Corsetti V, Middei S, Piccinin S, Della Valle F, Bussani R, Ammassari-Teule M, Nistico R, Calissano P, et al. (2018): AD-Related N-terminal truncated tau is sufficient to recapitulate in vivo the early perturbations of human neuropathology: Implications for immunotherapy. Mol. Neurobiol. $\mathbf{5 5}, 8124-8153$ https://doi.org/10.1007/s12035-018-0974-3

Braak H, Alafuzoff I, Arzberger T, Kretzschmar H, Del Tredici K (2006): Staging of Alzheimer disease-associated neurofibrillary pathology using paraffin sections immunocytochemistry. Acta Neuropathol. 112, 389-404 https://doi.org/10.1007/s00401-006-0127-z

Brotzakis YF, Lindstedt PR, Taylor R, Bernardes GJL, Vendruscolo M (2020): A structural ensemble of a tau-microtubule complex reveals regulatory tau phosphorylation and acetylation mechanisms. BioRxiv https://doi.org/10.1101/2020.11.10.376285

Bujotzek A, Lipsmeier F, Harris S.F, Benz J, Kuglstatter A, Georges G (2016): VH-VL orientation prediction for antibody humanization candidate selection: A case study. MAbs 8, 288-305 https://doi.org/10.1080/19420862.2015.1117720

Castellani RJ, Perry G (2019): Tau biology tauopathy traumatic brain injury and diagnostic challenges. J. Alzheimers Dis. 67, 447-467 https://doi.org/10.3233/JAD-180721

Cehlar O, Skrabana R, Dvorsky R, Novak M (2015): Structural insights into the conformation of the proline rich region of neuronal protein tau. Acta Crystallogr. A 71, S46-S47 https://doi.org/10.1107/S2053273315099271

Chapuis J, Hansmannel F, Gistelinck M, Mounier A, Van Cauwenberghe C, Kolen KV, Geller F, Sottejeau Y, Harold D, Dourlen P, et al. (2013): Increased expression of BIN1 mediates Alzheimer genetic risk by modulating tau pathology. Mol. Psychiatry 18, 1225-1234 https://doi.org/10.1038/mp.2013.1

Chen D, Drombosky KW, Hou Z, Sari L, Kashmer OM, Ryder BD, Perez VA, Woodard D.R, Lin MM, Diamond MI, et al. (2019): Tau local structure shields an amyloid-forming motif and controls aggregation propensity. Nat. Commun. 10, 2493 https://doi.org/10.1038/s41467-019-10355-1

Chukwu JE, Pedersen JT, Pedersen LO, Volbracht C, Sigurdsson EM, Kong XP (2018): Tau antibody structure reveals a molecular switch defining a pathological conformation of the tau protein. Sci. Rep. 8, 6209 https://doi.org/10.1038/s41598-018-24276-4

Chukwu JE, Congdon EE, Sigurdsson EM, Kong XP (2019): Structural characterization of monoclonal antibodies targeting C-terminal Ser(404) region of phosphorylated tau protein. MAbs 11, 477-488 https://doi.org/10.1080/19420862.2019.1574530 
Cino EA, Choy WY, Karttunen M (2013a): Conformational biases of linear motifs. J. Phys. Chem. B 117, 15943-15957 https://doi.org/10.1021/jp407536p

Cino EA, Killoran RC, Karttunen M, Choy WY (2013b): Binding of disordered proteins to a protein hub. Sci. Rep. 3, 2305 https://doi.org/10.1038/srep02305

Congdon EE, Lin Y, Rajamohamedsait HB, Shamir DB, Krishnaswamy S, Rajamohamedsait WJ, Rasool S, Gonzalez V, Levenga J, Gu J, et al. (2016): Affinity of Tau antibodies for solubilized pathological Tau species but not their immunogen or insoluble Tau aggregates predicts in vivo and ex vivo efficacy. Mol. Neurodegener. 11, 62 https://doi.org/10.1186/s13024-016-0126-z

Davey NE (2019): The functional importance of structure in unstructured protein regions. Curr. Opin. Struct. Biol. 56, 155-163 https://doi.org/10.1016/j.sbi.2019.03.009

Derreumaux P, Man VH, Wang J, Nguyen PH (2020): Tau R3-r4 domain dimer of the wild type and phosphorylated Ser356 sequences. I. In solution by atomistic simulations. J. Phys. Chem. B 124, 2975-2983 https://doi.org/10.1021/acs.jpcb.0c00574

Dregni AJ, Mandala VS, Wu H, Elkins MR, Wang HK, Hung I, DeGrado WF, Hong M (2019): In vitro 0N4R tau fibrils contain a monomorphic beta-sheet core enclosed by dynamically heterogeneous fuzzy coat segments. Proc. Natl. Acad. Sci. USA 116, 16357-16366 https://doi.org/10.1073/pnas.1906839116

Dyson HJ, Wright PE (2005): Intrinsically unstructured proteins and their functions. Nat. Rev. Mol. Cell Biol. 6, 197-208 https://doi.org/10.1038/nrm1589

Eisenberg DS, Sawaya MR (2017): Structural studies of amyloid proteins at the molecular level. Annu. Rev. Biochem. 86, 69-95

https://doi.org/10.1146/annurev-biochem-061516-045104

Elbaum-Garfinkle S, Rhoades E (2012): Identification of an aggregation-prone structure of tau. J. Am. Chem. Soc. 134, $16607-16613$ https://doi.org/10.1021/ja305206m

Esposito G, Viglino P, Novak M, Cattaneo A (2000): The solution structure of the C-terminal segment of tau protein. J. Pept. Sci. 6, 550-559

https://doi.org/10.1002/1099-1387(200011)6:11<550::AID-PSC272>3.0.CO;2-S

Falcon B, Zhang WJ, Murzin AG, Murshudov G, Garringer HJ, Vidal R, Crowther RA, Ghetti B, Scheres SHW, Goedert M (2018a): Structures of filaments from Pick's disease reveal a novel tau protein fold. Nature 561, 137-140 https://doi.org/10.1038/s41586-018-0454-y

Falcon B, Zhang WJ, Schweighauser M, Murzin AG, Vidal R, Garringer HJ, Ghetti B, Scheres SHW, Goedert M (2018b): Tau filaments from multiple cases of sporadic and inherited Alzheimer's disease adopt a common fold. Acta Neuropathol. 136, 699-708 https://doi.org/10.1007/s00401-018-1914-z

Falcon B, Zivanov J, Zhang WJ, Murzin AG, Garringer HJ, Vidal R, Crowther RA, Newell KL, Ghetti B, Goedert M, et al. (2019): Novel tau filament fold in chronic traumatic encephalopathy encloses hydrophobic molecules. Nature 568, 420-423 https://doi.org/10.1038/s41586-019-1026-5

Fandrich M (2012): Oligomeric intermediates in amyloid formation: structure determination and mechanisms of toxicity. J. Mol. Biol. 421, 427-440 https://doi.org/10.1016/j.jmb.2012.01.006

Fischer I, Baas PW (2020): Resurrecting the mysteries of big tau. Trends Neurosci. 43, 493-504 https://doi.org/10.1016/j.tins.2020.04.007

Fisher CK, Stultz CM (2011): Constructing ensembles for intrinsically disordered proteins. Curr. Opin. Struct. Biol. 21, 426-431 https://doi.org/10.1016/j.sbi.2011.04.001

Fitzpatrick AWP, Falcon B, He S, Murzin AG, Murshudov G, Garringer HJ, Crowther RA, Ghetti B, Goedert M, Scheres SHW (2017): Cryo-EM structures of tau filaments from Alzheimer's disease. Nature 547, 185-190 https://doi.org/10.1038/nature23002

Fontela YC, Kadavath H, Biernat J, Riedel D, Mandelkow E, Zweckstetter M (2017): Multivalent cross-linking of actin filaments and microtubules through the microtubule-associated protein Tau. Nat. Commun. 8, 1981 https://doi.org/10.1038/s41467-017-02230-8

Gandhi NS, Landrieu I, Byrne C, Kukic P, Amniai L, Cantrelle FX, Wieruszeski JM, Mancera RL, Jacquot Y, Lippens G (2015): A phosphorylation-induced turn defines the Alzheimer's disease AT8 antibody epitope on the tau protein. Angew. Chem. Int. Edit. 54, 6819-6823 https://doi.org/10.1002/anie.201501898

Goedert M, Spillantini MG, Jakes R, Rutherford D, Crowther RA (1989): Multiple isoforms of human microtubule-associated protein-tau-sequences and localization in neurofibrillary tangles of Alzheimers-disease. Neuron 3, 519-526 https://doi.org/10.1016/0896-6273(89)90210-9

Hanes J, Kovac A, Kvartsberg H, Kontsekova E, Fialova L, Katina S, Kovacech B, Stevens E, Hort J, Vyhnalek M, et al. (2020): Evaluation of a novel immunoassay to detect p-tau Thr217 in the CSF to distinguish Alzheimer disease from other dementias. Neurology 95, e3026-e3035 https://doi.org/10.1212/WNL.0000000000010814

Jebarupa B, Muralidharan M, Arun A, Mandal AK, Mitra G (2018): Conformational heterogeneity of tau: Implication on intrinsic disorder acid stability and fibrillation in Alzheimer's disease. Biophys. Chem. 241, 27-37

https://doi.org/10.1016/j.bpc.2018.07.005

Jeganathan S, von Bergen M, Brutlach H, Steinhoff HJ, Mandelkow $\mathrm{E}$ (2006): Global hairpin folding of tau in solution. Biochemistry 45, 2283-2293 https://doi.org/10.1021/bi0521543

Joo Y, Schumacher B, Landrieu I, Bartel M, Smet-Nocca C, Jang A, Choi HS, Jeon NL, Chang KA, Kim HS, et al. (2015): Involvement of 14-3-3 in tubulin instability and impaired axon development is mediated by Tau. FASEB J. 29, 4133-4144 https://doi.org/10.1096/f.14-265009

Kadavath H, Cabrales Fontela Y, Jaremko M, Jaremko L, Overkamp K, Biernat J, Mandelkow E, Zweckstetter M (2018): The binding mode of a tau peptide with tubulin. Angew. Chem. Int. Edit. 57, 3246-3250 https://doi.org/10.1002/anie.201712089 
Kadavath H, Jaremko M, Jaremko L, Biernat J, Mandelkow E, Zweckstetter M (2015): Folding of the tau protein on microtubules. Angew. Chem. Int. Edit. 54, 10347-10351 https://doi.org/10.1002/anie.201501714

Kellogg EH, Hejab NMA, Poepsel S, Downing KH, DiMaio F, Nogales E (2018): Near-atomic model of microtubule-tau interactions. Science 360, 1242-1246 https://doi.org/10.1126/science.aat1780

Kontsekova E, Zilka N, Kovacech B, Novak P, Novak M (2014a) First-in-man tau vaccine targeting structural determinants essential for pathological tau-tau interaction reduces tau oligomerisation and neurofibrillary degeneration in an Alzheimer's disease model. Alzheimers Res. Ther. 6, 44 https://doi.org/10.1186/alzrt278

Kontsekova E, Zilka N, Kovacech B, Skrabana R, Novak M (2014b) Identification of structural determinants on tau protein essential for its pathological function: novel therapeutic target for tau immunotherapy in Alzheimer's disease. Alzheimers Res. Ther. 6, 45 https://doi.org/10.1186/alzrt277

Kovacech B, Novak M (2010): Tau truncation is a productive posttranslational modification of neurofibrillary degeneration in Alzheimer's disease. Curr. Alzheimer Res. 7, 708-716 https://doi.org/10.2174/156720510793611556

Lasorsa A, Malki I, Cantrelle FX, Merzougui H, Boll E, Lambert JC, Landrieu I (2018): Structural basis of tau interaction with BIN1 and regulation by tau phosphorylation. Front. Mol. Neurosci. 11, 421 https://doi.org/10.3389/fnmol.2018.00421

Lazar T, Martinez-Perez E, Quaglia F, Hatos A, Chemes LB, Iserte JA, Mendez NA, Garrone NA, Saldano TE, Marchetti J, et al. (2021): PED in 2021: a major update of the protein ensemble database for intrinsically disordered proteins. Nucleic Acids Res. 49, D404-D411 https://doi.org/10.1093/nar/gkaa1021

Li CZ, Gotz J (2017): Tau-based therapies in neurodegeneration: opportunities and challenges. Nat. Rev. Drug. Discov. 16, 863-883 https://doi.org/10.1038/nrd.2017.155

Lippens G, Gigant B (2019): Elucidating Tau function and dysfunction in the era of cryo-EM. J. Biol. Chem. 294, 9316-9325 https://doi.org/10.1074/jbc.REV119.008031

Lyons AJ, Gandhi NS, Mancera RL (2014): Molecular dynamics simulation of the phosphorylation-induced conformational changes of a tau peptide fragment. Proteins 82, 1907-1923 https://doi.org/10.1002/prot.24544

Malia TJ, Teplyakov A, Ernst R, Wu SJ, Lacy ER, Liu XS, Vandermeeren M, Mercken M, Luo JQ, Sweet RW, et al. (2016): Epitope mapping and structural basis for the recognition of phosphorylated tau by the anti-tau antibody AT8. Proteins 84, 427-434 https://doi.org/10.1002/prot.24988

Manger LH, Foote AK, Wood SL, Holden MR, Heylman KD, Margittai M, Goldsmith RH (2017): Revealing conformational variants of solution-phase intrinsically disordered tau protein at the single-molecule level. Angew. Chem. Int. Edit. 56, 15584-15588 https://doi.org/10.1002/anie.201708242

Melkova K, Zapletal V, Narasimhan S, Jansen S, Hritz J, Skrabana R, Zweckstetter M, Ringkjobing Jensen M, Blackledge M,
Zidek L (2019): Structure and functions of microtubule associated proteins tau and MAP2c: Similarities and differences. Biomolecules 9, 105

https://doi.org/10.3390/biom9030105

Mercken M, Vandermeeren M, Lubke U, Six J, Boons J, Van de Voorde A, Martin JJ, Gheuens J (1992): Monoclonal antibodies with selective specificity for Alzheimer Tau are directed against phosphatase-sensitive epitopes. Acta Neuropathol. 84, 265-272 https://doi.org/10.1007/BF00227819

Milroy LG, Bartel M, Henen MA, Leysen S, Adriaans JM, Brunsveld L, Landrieu I, Ottmann C (2015): Stabilizer-guided inhibition of protein-protein interactions. Angew. Chem. Int. Edit. 54, 15720-15724 https://doi.org/10.1002/anie.201507976

Mirbaha H, Chen D, Morazova OA, Ruff KM, Sharma AM, Liu X, Goodarzi M, Pappu RV, Colby DW, Mirzaei H, et al. (2018): Inert and seed-competent tau monomers suggest structural origins of aggregation. Elife 7, e36584 https://doi.org/10.7554/eLife.36584

Mukrasch MD, Bibow S, Korukottu J, Jeganathan S, Biernat J, Griesinger C, Mandelkow E, Zweckstetter M (2009): Structural polymorphism of 441-residue tau at single residue resolution. PLoS Biol. 7, e34 https://doi.org/10.1371/journal.pbio.1000034

Mukrasch MD, von Bergen M, Biernat J, Fischer D, Griesinger C, Mandelkow E, Zweckstetter M (2007): The "jaws" of the tau-microtubule interaction. J. Biol. Chem. 282, 12230-12239 https://doi.org/10.1074/jbc.M607159200

Nakamura K, Greenwood A, Binder L, Bigio EH, Denial S, Nicholson L, Zhou XZ, Lu KP (2012): Proline isomer-specific antibodies reveal the early pathogenic tau conformation in Alzheimer's disease. Cell 149, 232-244 https://doi.org/10.1016/j.cell.2012.02.016

Neves JF, Petrvalska O, Bosica F, Cantrelle FX, Merzougui H, O'Mahony G, Hanoulle X, Obsil T, Landrieu I (2021): Phosphorylated full-length Tau interacts with 14-3-3 proteins via two short phosphorylated sequences each occupying a binding groove of 14-3-3 dimer. FEBS J. 288, 1918-1934 https://doi.org/10.1111/febs.15574

Nguyen PH, Ramamoorthy A, Sahoo BR, Zheng J, Faller P, Straub JE, Dominguez L, Shea JE, Dokholyan NV, De Simone A, et al. (2021): Amyloid oligomers: a joint experimental/computational perspective on Alzheimer's disease Parkinson's disease type ii diabetes and amyotrophic lateral sclerosis. Chem. Rev. 121, 2545-2647 https://doi.org/10.1021/acs.chemrev.0c01122

Novak M, Jakes R, Edwards PC, Milstein C, Wischik CM (1991): Difference between the tau-protein of Alzheimer paired helical filament core and normal tau revealed by epitope analysis of monoclonal antibodies-423 and antibodies-7.51. Proc. Natl. Acad. Sci. USA 88, 5837-5841

https://doi.org/10.1073/pnas.88.13.5837

Novak P, Schmidt R, Kontsekova E, Zilka N, Kovacech B, Skrabana R, Vince-Kazmerova Z, Katina S, Fialova L, Prcina M, et al. (2017): Safety and immunogenicity of the tau vaccine AADvac1 in patients with Alzheimer's disease: a randomised double-blind placebo-controlled phase 1 trial. Lancet Neurol. 16, 123-134 
https://doi.org/10.1016/S1474-4422(16)30331-3

Ovchinnikov S, Park H, Kim DE, DiMaio F, Baker D (2018): Protein structure prediction using Rosetta in CASP12. Proteins 86, (Suppl. 1) 113-121 https://doi.org/10.1002/prot.25390

Ozenne V, Schneider R, Yao MX, Huang JR, Salmon L, Zweckstetter M, Jensen MR, Blackledge M (2012): Mapping the potential energy landscape of intrinsically disordered proteins at amino acid resolution. J. Am. Chem. Soc. 134, 15138-15148 https://doi.org/10.1021/ja306905s

Pascual G, Wadia JS, Zhu X, Keogh E, Kukrer B, van Ameijde J, Inganas H, Siregar B, Perdok G, Diefenbach O, et al. (2017): Immunological memory to hyperphosphorylated tau in asymptomatic individuals. Acta Neuropathol. 133, 767-783 https://doi.org/10.1007/s00401-017-1705-y

Perini G, Ciasca G, Minelli E, Papi M, Palmieri V, Maulucci G, Nardini M, Latina V, Corsetti V, Florenzano F, et al. (2019): Dynamic structural determinants underlie the neurotoxicity of the N-terminal tau 26-44 peptide in Alzheimer's disease and other human tauopathies. Int. J. Biol. Macromol. 141, 278-289 https://doi.org/10.1016/j.ijbiomac.2019.08.220

Popov KI, Makepeace KAT, Petrotchenko EV, Dokholyan NV, Borchers CH (2019): Insight into the structure of the „unstructured" tau protein. Structure 27, 1710-1715 https://doi.org/10.1016/j.str.2019.09.003

Porzig R, Singer D, Hoffmann R (2007): Epitope mapping of mAbs AT8 and Tau 5 directed against hyperphosphorylated regions of the human tau protein. Biochem. Biophys. Res. Commun. 358, 644-649 https://doi.org/10.1016/j.bbrc.2007.04.187

Savastano A, Jaipuria G, Andreas L, Mandelkow E, Zweckstetter M (2020): Solid-state NMR investigation of the involvement of the P2 region in tau amyloid fibrils. Sci. Rep. 10, 21210 https://doi.org/10.1038/s41598-020-78161-0

Sawaya MR, Sambashivan S, Nelson R, Ivanova MI, Sievers SA, Apostol MI, Thompson MJ, Balbirnie M, Wiltzius JJ, McFarlane HT, et al. (2007): Atomic structures of amyloid cross-beta spines reveal varied steric zippers. Nature 447, 453-457 https://doi.org/10.1038/nature05695

Scheres SH, Zhang W, Falcon B, Goedert M (2020): Cryo-EM structures of tau filaments. Curr. Opin. Struct. Biol. 64, 17-25 https://doi.org/10.1016/j.sbi.2020.05.011

Schwalbe M, Kadavath H, Biernat J, Ozenne V, Blackledge M, Mandelkow E, Zweckstetter M (2015): Structural impact of tau phosphorylation at threonine 231. Structure 23, 1448-1458 https://doi.org/10.1016/j.str.2015.06.002

Schwalbe M, Ozenne V, Bibow S, Jaremko M, Jaremko L, Gajda M, Jensen MR, Biernat J, Becker S, Mandelkow E, et al. (2014): Predictive atomic resolution descriptions of intrinsically disordered htau40 and alpha-synuclein in solution from NMR and small angle scattering. Structure 22, 238-249 https://doi.org/10.1016/j.str.2013.10.020

Seidler PM, Boyer DR, Murray KA, Yang TXP, Bentzel M, Sawaya MR, Rosenberg G, Cascio D, Williams CK, Newell KL, et al. (2019): Structure-based inhibitors halt prion-like seeding by Alzheimer's disease-and tauopathy-derived brain tissue samples. J. Biol. Chem. 294, 16451-16464
https://doi.org/10.1074/jbc.RA119.009688

Seidler PM, Boyer DR, Rodriguez JA, Sawaya MR, Cascio D, Murray K, Gonen T, Eisenberg DS (2018): Structure-based inhibitors of tau aggregation. Nat. Chem. 10, 170-176 https://doi.org/10.1038/nchem.2889

Selenica MLB, Davtyan H, Housley SB, Blair LJ, Gillies A, Nordhues BA, Zhang B, Liu J, Gestwicki JE, Lee DC, et al. (2014): Epitope analysis following active immunization with tau proteins reveals immunogens implicated in tau pathogenesis. J. Neuroinflamm. 11, 152 https://doi.org/10.1186/s12974-014-0152-0

Sevcik J, Skrabana R, Dvorsky R, Csokova N, Iqbal K, Novak M (2007): X-ray structure of the PHF core C-terminus: Insight into the folding of the intrinsically disordered protein tau in Alzheimer's disease. FEBS Lett. 581, 5872-5878 https://doi.org/10.1016/j.febslet.2007.11.067

Shi Y, Murzin AG, Falcon B, Epstein A, Machin J, Tempest P, Newell KL, Vidal R, Garringer HJ, Sahara N, et al. (2021): Cryo-EM structures of tau filaments from Alzheimer's disease with PET ligand APN-1607. Acta Neuropathol. 141, 697-708 https://doi.org/10.1007/s00401-021-02294-3

Shih HH, Tu C, Cao W, Klein A, Ramsey R, Fennell BJ, Lambert M, Shuilleabhain DN, Autin B, Kouranova E, et al. (2012): An ultra-specific avian antibody to phosphorylated tau protein reveals a unique mechanism for phosphoepitope recognition. J. Biol. Chem. 287, 44425-44434 https://doi.org/10.1074/jbc.M112.415935

Sibille N, Huvent I, Fauquant C, Verdegem D, Amniai L, Leroy A, Wieruszeski JM, Lippens G, Landrieu I (2012): Structural characterization by nuclear magnetic resonance of the impact of phosphorylation in the proline-rich region of the disordered Tau protein. Proteins 80, 454-462 https://doi.org/10.1002/prot.23210

Sievers SA, Karanicolas J, Chang HW, Zhao A, Jiang L, Zirafi O, Stevens JT, Munch J, Baker D, Eisenberg D (2011): Structurebased design of non-natural amino-acid inhibitors of amyloid fibril formation. Nature 475, 96-100 https://doi.org/10.1038/nature10154

Skrabana R, Kontsek P, Mederlyova A, Iqbal K, Novak M (2004): Folding of Alzheimer's core PHF subunit revealed by monoclonal antibody 423. FEBS Lett. 568, 178-182 https://doi.org/10.1016/j.febslet.2004.04.098

Skrabana R, Filipcik P, Kovacech B, Zilka N, Weisova P, Fialova L, Hanes J, Kralovicova J, Kontsekova E, Barath P, et al. (2017): Flexible recognition of a flexible target: inhibition of tau protein oligomerization by DC8E8. Eur. Biophys. J. Biophys. Lett. 46, S396-S396

Sopko R, Golonzhka O, Arndt J, Quan C, Czerkowicz J, Cameron A, Smith B, Murugesan Y, Gibbons G, Kim SJ, et al. (2020): Characterization of tau binding by gosuranemab. Neurobiol. Dis. 146, 105120 https://doi.org/10.1016/j.nbd.2020.105120

Sottejeau Y, Bretteville A, Cantrelle FX, Malmanche N, Demiaute F, Mendes T, Delay C, Alves Dos Alves H, Flaig A, Davies P, et al. (2015): Tau phosphorylation regulates the interaction between BIN1's SH3 domain and Tau's proline-rich domain. Acta Neuropathol. Commun. 3, 58 https://doi.org/10.1186/s40478-015-0237-8 
Tsuchida T, Susa K, Kibiki T, Tsuchiya T, Miyamoto K, In Y, Minoura K, Taniguchi T, Ishida T, Tomoo K (2020): Crystal structure of the human tau PHF core domain VQIINK complexed with the Fab domain of monoclonal antibody Tau2r3. FEBS Lett. 594, 2140-2149 https://doi.org/10.1002/1873-3468.13791

Usardi A, Pooler AM, Seereeram A, Reynolds CH, Derkinderen P, Anderton B, Hanger DP, Noble W, Williamson R (2011): Tyrosine phosphorylation of tau regulates its interactions with Fyn SH2 domains but not SH3 domains altering the cellular localization of tau. FEBS J. 278, 2927-2937 https://doi.org/10.1111/j.1742-4658.2011.08218.x

Uversky VN, Oldfield CJ, Dunker AK (2008): Intrinsically disordered proteins in human diseases: introducing the D2 concept. Annu. Rev. Biophys. 37, 215-246

https://doi.org/10.1146/annurev.biophys.37.032807.125924

van Ameijde J, Crespo R, Janson R, Juraszek J, Siregar B, Verveen $\mathrm{H}$, Sprengers I, Nahar T, Hoozemans JJ, Steinbacher S, et al. (2018): Enhancement of therapeutic potential of a naturally occurring human antibody targeting a phosphorylated Ser(422) containing epitope on pathological tau. Acta Neuropathol. Commun. 6, 59 https://doi.org/10.1186/s40478-018-0562-9

Van Kolen K, Malia TJ, Theunis C, Nanjunda R, Teplyakov A, Ernst R, Wu SJ, Luo J, Borgers M, Vandermeeren M, et al. (2020): Discovery and functional characterization of hpt 3 a humanized anti-phospho tau selective monoclonal antibody. J. Alzheimers Dis. $77,1397-1416$ https://doi.org/10.3233/JAD-200544

van Zundert GCP, Rodrigues J, Trellet M, Schmitz C, Kastritis PL, Karaca E, Melquiond ASJ, van Dijk M, de Vries SJ, Bonvin A (2016): The HADDOCK2.2 Web Server: User-friendly integrative modeling of biomolecular complexes. J. Mol. Biol. 428, 720-725

https://doi.org/10.1016/j.jmb.2015.09.014

von Bergen M, Barghorn S, Li L, Marx A, Biernat J, Mandelkow EM, Mandelkow E (2001): Mutations of tau protein in frontotemporal dementia promote aggregation of paired helical filaments by enhancing local beta-structure. J. Biol. Chem. 276, 48165-48174 https://doi.org/10.1074/jbc.M105196200

von Bergen M, Friedhoff P, Biernat J, Heberle J, Mandelkow EM, Mandelkow E (2000): Assembly of tau protein into Alzheimer paired helical filaments depends on a local sequence motif ((306)VQIVYK(311)) forming beta structure. Proc. Natl. Acad. Sci. USA 97, 5129-5134

https://doi.org/10.1073/pnas.97.10.5129

Walker S, Ullman O, Stultz CM (2012): Using intramolecular disulfide bonds in tau protein to deduce structural features of aggregation-resistant conformations. J. Biol. Chem. 287, 9591-9600 https://doi.org/10.1074/jbc.M111.336107

Weisova P, Cehlar O, Skrabana R, Zilkova M, Filipcik P, Kovacech B, Prcina M, Wojciakova L, Fialova L, Smolek T, et al. (2019): Therapeutic antibody targeting microtubule-binding domain prevents neuronal internalization of extracellular tau via masking neuron surface proteoglycans. Acta Neuropathol. Commun. 7, 129 https://doi.org/10.1186/s40478-019-0770-y

Wintjens R, Wieruszeski JM, Drobecq H, Rousselot-Pailley P, Buee L, Lippens G, Landrieu I (2001): 1H NMR study on the binding of Pin1 Trp-Trp domain with phosphothreonine peptides. J. Biol. Chem. 276, 25150-25156 https://doi.org/10.1074/jbc.M010327200

Yang JY, Yan RX, Roy A, Xu D, Poisson J, Zhang Y (2015): The I-TASSER Suite: protein structure and function prediction. Nat. Methods 12, 7-8 https://doi.org/10.1038/nmeth.3213

Zhang H, Zhu XY, Pascual G, Wadia JS, Keogh E, Hoozemans JJ, Siregar B, Inganas H, Stoop EJM, Goudsmit J, et al. (2018): Structural basis for recognition of a unique epitope by a human anti-tau antibody. Structure 26, 1626-1634 https://doi.org/10.1016/j.str.2018.08.012

Zhang W, Falcon B, Murzin AG, Fan J, Crowther RA, Goedert M, Scheres SH (2019): Heparin-induced tau filaments are polymorphic and differ from those in Alzheimer's and Pick's diseases. Elife 8, e43584 https://doi.org/10.7554/eLife.43584.040

Zhang WJ, Tarutani A, Newell KL, Murzin AG, Matsubara T, Falcon B, Vidal R, Garringer HJ, Shi Y, Ikeuchi T, et al. (2020): Novel tau filament fold in corticobasal degeneration. Nature 580, 283-287 https://doi.org/10.1038/s41586-020-2043-0

Received: May 26, 2021

Final version accepted: July 13, 2021 